\title{
Marceli KOSMAN
}

Poznań

\section{$\mathrm{Na}$ tronie i obok tronu. O kobietach w życiu publicznym Polski przedrozbiorowej}

\section{Uwagi wstępne}

Cryderyk Henryk Lewestam, jeden z czołowych autorów fundamentalnego kompendium polskiego z połowy XIX wieku ${ }^{1}$, tak pisał w 1863 r.: Kobieta, wyraz w szlachetnym znaczeniu oznaczajacy cała płeć żeńska, jest reprezentantka obyczajności, miłości, sromu $i$ w ogóle bezpośredniego uczucia $w$ tych zwłaszcza narodach i przy takim rozwoju oświaty, przy którym stosunki płciowe $i$ powstałe stą zwiqzki pomiędzy niewiasta a mężczyzna przybraty już kierunek wyższy, moralny i estetyczny...2.

Jak rzeczy miały się w czasach Słowiańszczyzny pierwotnej? Sytuacja zależała od stanu cywilnego, inaczej bowiem kształtowało się położenie panien, mężatek i wdów. Te pierwsze, podobnie jak wszystkie dzieci, były podporządkowane władzy ojca, przy czym podróżnicy arabscy piszą o ich znacznej swobodzie obyczajowej. Po zawarciu małżeństwa panna przechodziła pod władzę męża, któremu winna była wierność, zaś jej naruszenie mogło doprowadzić do odesłania do domu rodzicielskiego. Cieszyła się prestiżem społecznym, mogła posiadać własny majątek, ale bez dysponowania dobrami mężowskimi. Była opiekunką domu i dzieci, w stosunku do których sprawowała też opiekę jako wdowa ${ }^{3}$.

Autor pierwszego tomu dziejów państwa i prawa Polski szczegółowo omawia sprawy związane z małżeństwem i rodziną w wiekach średnich. Zwraca uwagę na długo utrzymujące się małżeństwa umowne, zawierane bez udziału duchownego, ale publicznie wobec świadków. Były one zawierane bez zapowiedzi (te ogłaszano od soboru laterańskiego 1215 r.); Kościół traktował je jako tajemne, nie kwestionował ich ważności, ale nakazywał dodatkowo dopełnienia aktu ślubu kościelnego ${ }^{4}$.

Lewestam pisał w okresie walki kobiet o emancypację, toteż nie pominął kwestii funkcji społecznych reprezentantów obu płci, z widoczną rezerwą zauważając: ...Od wieków mężczyzna stanowit i tworzyt państwa i religie, systemata filozoficzne, pojęcia sztuki i nauki; kobieta uczestniczyła w tych jego rozwojach bi e r ny m raczej ws pó łc z uc i e m, a lubo mnó-

\footnotetext{
${ }^{1}$ Żył w latach 1817-1878, był z pochodzenia Duńczykiem, synem osiadłego w roku jego urodzenia w Warszawie stomatologa, pisał też pod pseudonimem K. Batornicki, znany jako krytyk literacki, historyk i tłumacz; profesor Szkoły Głównej Warszawskiej i Uniwersytetu Warszawskiego. Autor m.in. Pierwotnych dziejów Polski, Obrazu najnowszego ruchu literackiego w Polsce, Historii literatury powszechnej (4 tomy); erudyta i popularyzator. Zob. A. Przymusiała, Lewestam Fryderyk Henryk, w: Polski Słownik Biograficzny (dalej: PSB) XVII, 1972, s. 221 n.

${ }^{2}$ FHL, Kobieta, w: Encyklopedyja powszechna, nakład, druk i własność S/amuela/ Orgelbranda, Księgarza i Typografa, t. 14, Warszawa 1863, s. 943.

${ }^{3}$ S/tanisław/ R/ussocki/, Kobieta, w: Stownik (mały) kultury dawnych Stowian, pod red. L. Leciejewicza, wyd. III, Warszawa 1990, s. 176 n.

${ }^{4}$ J. Bardach, Historia państwa i prawa Polski (pod ogólną redakcją J. Bardacha), t. I: Do połowy XV wieku, wydanie drugie poprawione i uzupełnione, Warszawa 1964, s. 283-289.
} 
stwo kobiet zajmowało się i zajmuje naukami i sztukami pięknymi, przeciez $w$ gruncie rzeczy pozostaty one zawsze $i$ ws zędzie dylet tantkami, i nawet w poezji, pomimo catego częstokroć talentu i gustu, zupe tnie nowych torów do tad nigdy nie o d k ry ły. Najwyższym zwykle szczytem ich zdolności poetycznej sq romanse czyli powieści i egotyczne wylewy liryki. Tak samo $i$ wi elki e monarchinie wlaściwi e nigdy jeszcze nie stworzyty trwałych form i stosunków państwowych, jakkolwiek korzystnie działać mogly przez mężzyzn, których wybierały czestokroćz wielkim taktem...

Przy tej okazji warto przypomnieć popularną konstatację wielkiego poety czasów Oświecenia, księcia biskupa warmińskiego i późniejszego prymasa Ignacego Krasickiego, doskonałego znawcy płci pięknej, skierowaną do mężczyzn: my rzadzim światem, a nami kobiety... Nadchodziły nowe czasy, kiedy nie ukrywano wpływów niewieścich na życie publiczne za kotarą, a zachodzące procesy nie ominęły ziem polskich, choć zostały opóźnione ze względu na specyfikę życia narodu pod trzema zaborami, w obcych organizmach państwowych w ciagu 123 lat niewoli. Po odzyskaniu niepodległości swym znakomitym piórem nakreślił syntetycznie wiedzę o kobietach Aleksander Brückner w swej Encyklopedii staropolskiej opublikowanej pod koniec dwudziestolecia międzywojennego, kiedy stosowne hasło rozpoczął od informacji, że używanie określenia kobieta na oznaczenie płci żeńskiej przed wiekiem XIX byłoby grubym anachronizmem, pierwotnie bowiem miało ono charakter uszczypliwy i wzgardliwy. Na pytanie o jej stanowisko w Polsce ten polihistor ${ }^{6}$ tak odpowiada:

Pierwotnie jak najniższe: była kupiona, więc rzeczq, niewolnica, sługa, która za mężem na i stos szła, która jak obca rodowi żadnego prawa do dziedziczenia nie miała, która maż wedle woli karat za każde przestępstwo, śmierciq $w$ razie niewierności, jeśli nie zadowolit się specjalnq karq hańbiqca. Chrześcijaństwo od razu podniosło znaczenie kobiety już przez samo wymaganie jednożeństwa, co nadawato matżonce jakby jakieś równouprawnienie, dalej przez zakaz targnienia się na jej życie nawet $w$ razie niewier$n o s c^{7}$. Nowsze badania w szczegółach skorygowały niektóre opinie, generalnie jednak spojrzenie autora jest aktualne, zwłaszcza co do przełomu spowodowanego przez wprowadzenie chrześcijaństwa, które rzeczywiście stanowiło istotny krok na drodze do prawnej opieki nad kobietami, choć z drugiej strony usiłowało ograniczyć swobodę zakazując np. obcowania małżeńskiego podczas postów; ludzie jednak nie zawsze pozwalali klerowi zaglądać do swych łożnic, co nawet było znane, choć w takich sytuacjach kierowano się wyższymi racjami - jak donosi Anonim Gall księżniczka czeska Dobrawa, podobno za wiedzą spowiednika, współżyć miała z Mieszkiem w tym okresie, a to ze względu na nawracanie polańskiego władcy. Z kolei pójście na stos za zmarłym mężem zostało upowszechnione raczej w literaturze pięknej, głównie dzięki Starej baśni Józefa Ignacego Kraszewskiego (Wisz i Jaga). Obrona niewiernej żony, którą chcieli za-

\footnotetext{
${ }^{5}$ Lewestam, op. cit., s. 943. Podkreślenia moje - MK.

${ }^{6}$ Aleksander Brückner (1856-1939), wykształcony na uniwersytetach krajowych i zachodnich (Lipsk, Berlin, Wiedeń) historyk języka, literatury i kultury polskiej, slawista, edytor tekstów staropolskich, docent uniwersytetu we Lwowie, a od 1881 r. w Berlinie, badacz o wszechstronnych zainteresowaniach i olbrzymim dorobku (ponad 1500 pozycji), obejmującym czasy od początków piśmiennictwa polskiego do wieku XIX, w tym kilkakrotnie wznawianych syntez: Dzieje literatury polskiej w zarysie (2 tomy) oraz Dzieje kultury polskiej (4 tomy). Zob. Stownik historyków polskich, Warszawa 1994, s. 61; W trzydziestolecie śmierci Aleksandra Brücknera, pod red. T. Ulewicza, Kraków 1971.

${ }^{7}$ Encyklopedia staropolska, opracowanie A. Brückner, materiałem ilustracyjnym opatrzył K. Estreicher, t. I, Warszawa 1937, kol. 603 (cytuję za reprintem: Warszawa 1990).
} 
mordować krewni jej męża nie zważając na kościelne prawo azylu, gdy szukała schronienia przed ołtarzem, wiąże się z żywotem świętego Wojciecha jako biskupa Pragi.

Brückner dalej znakomicie szkicuje przemiany w społecznej pozycji kobiet w wiekach średnich (nie szczędzi trafnych uwag związanych z nierzadkim spadaniem prowadzenia gospodarstwa na ramiona niewiasty, zwłaszcza wobec pijaństwa, lenistwa czy niezaradności chłopa czy - dodajmy - jego choroby lub zaawansowanego wieku, co wcale nie należało do rzadkości). W stanie rycerskim zmiany następowały szybciej, pierwotnie panie były całkowicie pozbawione prawa do dziedziczenia, w braku potomstwa dobra przechodziły w ręce krewniaków zmarłego. Z czasem i one mogły dziedziczyć, a w szerszym znaczeniu prawdziwe przemiany przyniósł Złoty Wiek i czasy Reformacji, której gorącymi zwolenniczkami było wiele białogłów, również w czasach prześladowań jej zwolenników, kiedy nastąpiło wygnanie arian z Rzeczypospolitej.

Żyły też kobiety polskie cicho $w$ domu, statecznie tym bardziej, czym więcej mężowie statek tracili - pisze badacz ${ }^{8}$ i jest to opinia trafna, choć w kręgach możnowładczych i zamożnej szlachty emancypacja była coraz bardziej widoczna. Prawdziwa rewolucja wiązała się z Włoszką na polskim tronie, choć - trzeba przyznać - przykład Bony nie zyskał powszechnego uznania. Do tej sprawy wrócimy, tu zaznaczając, że - zgodnie z powiedzeniem: gutta cavat lapidem, czyli kropla drąży skałę - jej następczynie, tym razem pochodzące znad Sekwany, wywarły silny wpływ na rolę pań w życiu publicznym, oczywiście tych ,z najwyższej półki”, czyli z czołowych rodów magnackich. Prawdziwa rewolucja następowała w modzie XVII, a zwłaszcza XVIII wieku, co gorszyło moralistów - Wacław Potocki pisał, że żadna bogobojna panna, mężatka czy wdowa nie będzie pozostawać sam na sam z mężczyzna, nawet dla odmawiania pacierzy, widocznie więc inaczej bywało; co gorsza, białogłowy zaczęły się włóczyć po cudzych krajach.

Tak przełamaty Polki dotychczasowy monopol mężczyzn. Ale to byt dopiero poczatek. Za Sasów zly przyktad szedt od góry, bo szlafrok (August III) i jego żona (dewotka) naprawić nie zdołali zła, które rozsiał August II [...] Za Sasów i Stanisława Augusta góruje przeciętna kobieta co do inteligencji nad przeciętnym mężczyznq - biada znawca kultury staropolskiej - dodając na uzasadnienie tej nieco upraszczającej sprawę konstatacji: Już to samo, że nierównie więcej pań umiało i czytało po francusku niż mężczyźni, korzystnie o nich świadczyło. Udziat kobiet $w$ literaturze, choćby tylko tlumaczek, w porównaniu z XVII w. byt nierównie obfitszy [...] Bywało, maż jeszcze , sarmata”, żona już modnisia i dzieci w tym duchu wychowywała (jeśli o to dbała $)^{9}$.

Znawcy czasów staropolskich zwracają uwagę na rozpowszechnienie od połowy XVII w. - a zwłaszcza w następnym stuleciu - rozwodów, przede wszystkim w samej szybko europeizującej się Warszawie, gdzie miało ich być więcej niż w całej Koronie i Litwie razem wziętych. Oczywiście dotyczyło to najzamożniejszych spośród „dobrze urodzonych”, ale ta jedynie warstwa społeczna stanowi przedmiot naszego zainteresowania.

Ostatnimi laty ukazało się szereg książek - przeważnie o charakterze sensacyjnym i niewielkiej wartości merytorycznej - poświęconych wybitnym kobietom w dziejach, głównie zbiory szkiców o wybranych postaciach. Niektóre doczekały się interesujących monografii - przykładowo wymienię angielską , żelazną damę”, Margaret Tchatcher, autorstwa jednego z najbliższych współpracowników, w 2010 r. opublikowana też w przekładzie polskim przez

\footnotetext{
${ }^{8}$ Ibidem, kol. 606.

${ }^{9}$ Ibidem, kol. 607 n.
} 
poznańskie wydawnictwo „Zysk” dla upamiętnienia nadania jej doktoratu honoris causa Uniwersytetu Ekonomicznego w tym mieście - w tym kilka naszych monarchiń, niekoniecznie wybitnych, bo wśród nich znalazła się np. postać ostatniej Jagiellonki, którą jedynie wydarzenia wyniosły w swoim czasie na tron.

Na koniec tych uwag o charakterze ogólnym zwróćmy uwagę na kompetentnie napisane i opublikowane u schyłku XX wieku życiorysy historyczne i legendarne pod redakcją Zofii Stefanowskiej i Janusza Tazbira, które w trzech tomach obejmują 31 postaci z minionego tysiąclecia, z tego 20 żyjących w czasach przedrozbiorowych. Dobór nie był przypadkowy, choć kontynuacja tego przerwanego niestety cyklu pozwoliłaby uwzględnić szereg innych równie znanych, a często kontrowersyjnie ocenianych osób. Wśród nich dominowali władcy (Bolesław Chrobry, Bolesław Śmiały, Władysław Łokietek, Kazimierz Wielki, Władysław Jagiełło, Zygmunt August, August II Mocny, Stanisław August Poniatowski) ale znalazły się też monarchinie: Barbara Radziwiłłówna, Bona Sforza d'Aragona, Ludwika Maria Gonzaga oraz Maria Kazimiera ${ }^{10}$.

\section{2. Żony panujących $\mathrm{z}$ dynastii piastowskiej}

W najstarszej kronice polskiej pierwsza wzmianka o niewieście dotyczy żony protoplasty Piastów $^{11}$, Rzepki, która przeszła do legendy dziejowej pod imieniem Rzepicha. Oboje byli bohaterami sceny z udziałem tajemniczych przybyszów, przez legendę dziejową utożsamianych z Cyrylem i Metodym, misjonarzami Słowian wielkomorawskich w obrządku wschodnim.

Kronikarz wiele miejsca poświęcił początkom dynastii, ale krótko wspomniał o jej pierwszych przedstawicielach (wspomniany Siemowit, Lestek i Siemomysł), toteż ich historyczność przez krytycznych badaczy w XIX i XX w. była kwestionowana. Na twardy grunt wyprowadził dzieje dopiero wraz z Mieszkiem (ok. 990-992), a konkretnie okolicznościami przyjęcia przezeń chrztu, którego inicjatorką uczynił jego małżonkę:

Mieszko objawszy księstwo zacząt dawać dowody zdolności umystu i sit cielesnych i coraz częściej napastować ludy (sqsiednie) dookoła. Dotychczas jednak w takich pograżony byt błędach pogaństwa, że wedle swego zwyczaju siedmiu żon zażywat. W końcu zażadat w małżeństwo jednej bardzo dobrej chrześcijanki z Czech, imieniem Dąrówka ${ }^{12}$. Lecz ona odmówita poślubienia go, jeśli nie zarzuci owego zdrożnego obyczaju $i$ nie przyrzeknie zostać chrześcijaninem. Gdy zaś on (na to) przystat, że porzuci ów zwyczaj pogański i przyjmie sakramenta wiary chrześcijańskiej, pani owa przybyła do Polski $z$ wielkim orszakiem (dostojników) świeckich i duchownych, ale nie pierwej podzieliła z nim toże matżeńskie, aż powoli a pilnie zaznajamiajac się z obyczajem chrześcijańskim i prawami kościelnymi, wyrzekt się błędów pogaństwa i przeszedt na łono matki - Kościoła ${ }^{13}$.

\footnotetext{
${ }^{10}$ Życiorysy historyczne, literackie i legendarne, seria pierwsza, druga i trzecia, pod red. Z. Stefanowskiej, J. Tazbira, Warszawa 1980 (wyd. II, 1984), 1989, 1992. Dla pełniejszego obrazu wymieńmy pozostałą panią, była to Emilia Plater. W zbiorze znalazła się jedna koronowana para: Zygmunt August oraz jego druga żona, Barbara.

${ }^{11}$ Piast miał być ubogim kmieciem, oraczem książęcym za czasów okrutnego Popiela, przeciw któremu wybuchł bunt. Wyniósł on do władzy młodego Siemowita, syna Piastowego. Zob. Anonim tzw. Gall, Kronika polska, przełożył R. Grodecki, przekład przejrzał i przypisami opatrzył M. Plezia, „Biblioteka Narodowa” seria I, nr 59, s. 12 nn.

${ }^{12}$ Dobrawa, córka księcia Bolesława Srogiego z dynastii Przemyślidów, została poślubiona Mieszkowi w 965 r., zmarła w 977. Zob. H. Łowmiański, Religia Słowian i jej upadek (w. VI-XII), Warszawa 1979, s. 302-317; idem, Poczqtki Polski. Z dziejów Stowian w I tysiącleciu, t. V, Warszawa 1973, s. 575 nn.

${ }^{13}$ Anonim Gall, op. cit., s. 18 n.
} 
Pobożny zakonnik, którego imienia nie znamy, zakonkludował, że chrzest Mieszka nastąpił za sprawą wiernej żony ${ }^{14}$. I taka wersja utrzymywała się w edukacji historycznej Polski przedrozbiorowej aż do początków przełomu oświeceniowego. Dziś wiemy, że sprawa była złożona, a inicjatywa porzucenia starych bogów i wejścia do kręgu cywilizacji europejskiej wyszła bez wattpienia od władcy Polan, polityka wybitnego, ambitnego, ale i dalekowzrocznego, łączącego walory stratega i taktyka, twórcy podwalin państwowości, którą utrwalił syn i kontynuator jego dzieła, Bolesław Chrobry ${ }^{15}$. Przy tym autor najnowszej monografii poświęconej pierwszemu historycznemu władcy, który mu wystawił bardzo wysoką ocenę jako mężowi stanu, z pełnym uznaniem wyraził się o jego pierwszej małżonce i jej charakterze, choć wzmianki źródłowe na ten temat są skape, a nawet ze sobą sprzeczne: ...była to pani nie tylko światobliwa, ale także rozumna i dzielna, niematy też pewnie wywierała wptyw na sprawy państwa. Domyślać się tego można choćby stad, że wnet po jej śmierci doszło do zerwania z Czechami, czego następstwem byt, jak się zdaje, m.in. najazd ruski na Grody Czerwieńskie w r. 981. Nic też dziwnego, że pamięć jej pozostała na zawsze żywa w całym narodzie... ${ }^{16}$.

Natomiast nie zasłużyła na podobną pamięć jej następczyni u boku Mieszka I, Niemka Oda, córka margrabiego Marchii Północnej Dytryka. Również to małżeństwo, zawarte około 980 r., miało charakter typowo polityczny. Po śmierci męża została wygnana przez dorosłego pasierba Bolesława Chrobrego i schroniła się w ojczyźnie wraz z trzema małoletnimi synami, Mieszkiem, Świętopełkiem i Lambertem. Pozwoliło to zachować całość młodego państwa przed planowanym podziałem na części wielkopolską (gnieźnieńską) i małopolską (krakowską), pierwszą przewidzianą dla nich pod opieką Ody, a drugą dla pierworodnego syna Mieszkowego ${ }^{17}$.

Cofnijmy się teraz do czasów legendarnych, jako że Małopolanin Wincenty zwany Kadłubkiem w swej młodszej o całe stulecie od Gallowej kronice postanowił cofnać do czasów starożytnych początki polskiej państwowości, lokując je w swojej rodzimej dzielnicy. W jego fantazyjnym dziele pojawili się Krakus (Grakchus), dwóch Lestków, a także Wanda. Wiele miejsca poświęcił ich nadwiślańskiej stolicy i siedzibie władców na Wawelu. Ta oczywiście miała historyczną proweniencję, natomiast wspomniane postacie - w tym i pierwszą niewiastę na tronie - z całym przekonaniem odłożyć należy do dziejowej legendy ${ }^{18}$.

Historycy, autorzy kolejnych genealogii Piastów, od Oswalda Balzera do Kazimierza Jasińskiego (odsyłamy na tym miejscu do ich fundamentalnych dzieł, a także do syntetycznych zestawień w syntezie Włodzimierza Dworzaczka) zestawili dane o całym królewskim rodzie, który dotrwał - zniemczały - do połowy XVII wieku, a w naszych dziejach zasiadał na tronie od X do trzeciej ćwierci XIV stulecia, Mazowszem zaś władał do 1526 r. ${ }^{19}$

\footnotetext{
${ }^{14}$ Ibidem, s. 19

15 Zob. G. Labuda, Mieszko I, Wrocław-Warszawa-Kraków 2002, s. 224 nn.

${ }^{16}$ Idem, Dobrawa, pierwsza chrześcijańska księżna polska, PSB V (1939-1946), s. 240 nn. Warto zauważyć, że niemiecki kronikarz Thietmar z Merseburga, piszący po łacinie podaje jej imię w wersji „Bona”, a więc tożsamej ze słynną królową z XVI stulecia.

${ }^{17}$ Idem, Oda, zm. 1023, PSB XXIII (1978), s. 530 n.

${ }^{18}$ Szerzej w najnowszej literaturze zob. J. Banaszkiewicz, Polskie dzieje bajeczne Mistrza Wincentego Kadlubka, Wrocław 1998, rozdział poświęcony Wandzie, s. 65 nn. Olśniewającej piękności bohaterska córka Kraka miała prowadzić do boju z najeźdźcami swe wojska w pierwszej wojnie obronnej młodego państwa polskiego.

${ }^{19}$ O. Balzer, Genealogia Piastów, Kraków 1895 (reprint: Warszawa 1980); K. Jasiński, Rodowód Piastów śląskich, t. I-III, Wrocław 1973-1977 (i liczne inne studia); W. Dworzaczek, Genealogia, Warszawa 1959; Dynastie Europy, pod red. A. Mączaka, Warszawa 2003 (tam tablice genealogiczne rodów panujących, m.in. Piastów, Jagiellonów i Wazów).
} 
W odniesieniu do Mieszka I mówi się o kilku hipotetycznych żonach pogańskich, o których nie wiemy nic konkretnego, poprzedniczkach Dobrawy i Ody. Książę ten pojmując Czeszkę liczył czterdzieści kilka lat i najpewniej nie żył w celibacie, tyle że nic nie wiadomo o jego potomstwie z czasów pogańskich. Bolesław Chrobry miał cztery żony, przy czym nie znamy imion dwóch pierwszych, córki margrabiego Miśni Rydgara (984) i księżniczki węgierskiej (986), którą odprawił na dwór ojca Gejzy wraz z synem Bezprymem. Jego trzecie małżeństwo - z Emnildą, córką zachodniosłowiańskiego księcia Dobromira, zawarte w 987 roku i trwające do jej śmierci w 1017 r., było trwałe i udane. Gall poświęcił księżnej obszerny rozdział w swej kronice, eksponując wpływ na porywczego małżonka: nieraz bowiem kobieta madra i roztropna, wielu wydanych na śmierć za przestępstwo wyrwała z rakk pachołków, ocaliła od bezpośredniego niebezpieczeństwa śmierci $i w$ więzieniu, pod straża zachowała ich miłosiernie przy życiu, niekiedy bez wiedzy króla, a kiedy indziej za jego milczaca zgoda ${ }^{20}$.

Wkrótce po jej śmierci Bolesław zawarł czwarte małżeństwo, z Odą, córką margrabiego miśnieńskiego Ekkeharda, która po śmierci męża (1025) zapewne wróciła do ojczyzny. Nie ma dowodów, by wraz z nim była koronowana. A Bolesław wkrótce po ślubie podczas wyprawy kijowskiej wziął za nałożnicę tamtejszą księżniczkę Przedsławę (wcześniej odmówiono mu jej ręki), którą prawdopodobnie uwiózł ze sobą wracając do kraju ${ }^{21}$.

Piastowie zasiadający na tronie polskim zawierali małżeństwa niemal wyłącznie z księżniczkami niemieckimi lub ruskimi. Po śmierci mężów wdowy sprawowały - wraz z dostojnikami - opiekę nad małoletnimi następcami tronu ${ }^{22}$. Taką rolę pełniła - po nagłej śmierci w 1194 r. Kazimierza Sprawiedliwego - Helena, córka jednego z książąt ruskich, wedle Mistrza Wincentego kobieta madra ponad madrość kobieca, matka kilkuletnich Leszka Białego i Konrada Mazowieckiego. Syn pierwszego z nich, Bolesław Wstydliwy uzyskał ów przydomek od umowy z poślubioną w 1239 r. Kingą, córką króla Węgier Beli IV o powstrzymaniu się od współżycia seksualnego, zgodnie z modną w wieku XIII ascezą chrześcijańską. Przeżyła męża o trzynaście lat i zmarła w 1292 r. w klasztorze, zgodnie z obyczajem niejednej wdowy po piastowskim władcy. Ślub czystości złożony przez parę książęcą wspominają ówczesne źródła, a sławny XVIII-wieczny encyklopedysta ksiądz Benedykt Chmielowski pisał z charakterystyczną dlań fantazją o wielkiej modestyi i oczach opuszczonych Bolesława.

Skrajnie odmiennym przykładem jest Gryfina, córka Rościsława, bana naddunajskiej Maczwy, żona Leszka Czarnego, poślubiona przezeń w 1265 r. Młodsza o kilka lat od męża, publicznie oskarżyła go o zaniedbywanie obowiązków małżeńskich i przez kilka lat pozostawała z nim w separacji, zanim się pogodzili. Przeżyła go o dwa dziesięciolecia, jako wdowa przebywała w rodzinnych stronach i pochowana została u franciszkanów w Pradze ${ }^{23}$.

Wkrótce po zjednoczeniu ziem polskich przez Władysława Łokietka doszło do konfliktu na tronie między teściową i synową. Pierwsza to żona władcy, Jadwiga, Piastówna z dzielnicy kaliskiej, poślubiona przezeń najpewniej w 1293 r. Wniosła niewielki posag, ale po Przemyśle II odziedziczyła dla męża Wielkopolskę. W 1320 r. została ukoronowana wraz z mężem na Wawelu, a po jego śmierci (1333) protestowała przeciw koronacji - wraz z następcą - jego żony, Aldony - Anny, córki w.ks. litewskiego Giedymina. Protesty na nic się zdały, toteż otrzymawszy uposażenie wdowie usunęła się zaraz do klasztoru klarysek w Sączu, gdzie po

\footnotetext{
${ }^{20}$ Anonim Gall, op. cit., s. 34.

${ }^{21}$ Gall, op. cit., s. 24; R. Grodecki, Emnilda, PSB VI (1948), s. 267; G. Labuda, Oda, księżna polska, PSB XXIII (1978), s. 531.

${ }^{22}$ Zob. Poczet królów i ksiażąt polskich, Warszawa 1980, a także biogramy w PSB.

${ }^{23}$ M. Piszczkowska, Gryfina, PSB IX (1960-1961), s. 72 n.
} 
czterech latach przywdziała habit zakonny. Zapewne tam została pochowana w 1339 r., nie ma bowiem śladu by spoczęła u boku męża na Wawelu. Utrzymywała - nawet jako mniszka - dwór z urzędnikami, a w dokumentach tytułowała się: królowa Polski i pani ziemi sqdeckiej. Jan Długosz notuje: ...starsza królowa Jadwiga, wdowa po królu Władysławie, a matka księcia Kazimierza wniosła sprzeciw $i$ wysunęła wiele przeszkód przeciw koronacji żony Kazimierza Anny. Twierdziła bowiem, że jak długo ona żyje, nie można bez pogwałcenia prawa ukoronować zgodnie z przepisami innej kobiety. W końcu nakłoniona prośbami wspomnianego syna, księcia Kazimierza, którego kochała więcej niż macierzyńska miłościa, pozwala z całym spokojem nie tylko na koronacje jego żony, ale uznawszy, że będzie wystarczajaco szczęśliwa, jeśli zobaczy syna na tronie $i$ w koronie królewskiej, usunęła się do klasztoru sióstr do Starego Sacza i tam przywdziawszy strój zakonny i przyjawszy regułę św. Franciszka, żyjac pobożnie, wypetniła resztę życia postami i modłami ${ }^{24}$.

Nie było miejsca na dwie królowe u boku monarchy. Ale ostatni z Piastów na polskim tronie starał się nieco poluźnić krępujące go ślubem w kościele więzy. Kazimierz III Wielki po śmierci Anny (zmarła w tym samym co teściowa 1339 r.) dobiegał trzydziestki, a z małżeństwa tego narodziła się jedynie córka Elżbieta, a kobiety wówczas nie dziedziczyły tronu w Polsce. Toteż wkrótce pojął Adelajdę, córkę landgrafa heskiego Henryka, jednakże wkrótce oddalił ją od siebie i osadził w jednym z zamków, podejmując starania o rozwód. Znakomity władca nie stronił od miłostek, m.in. w 1357 r. jedna z nich zakończyła się potajemnym ślubem w Pradze z Krystyną, wdową po Mikuszu Rokiczańskim, która oczywiście żadnych praw monarszych nie miała. Co więcej, ślub oznaczał bigamię, podobnie jak zawarte za życia Adelajdy i Krystyny czwarte małżeństwo, z księżniczką żagańską Jadwigą. Miało ono charakter morganatyczny i choć z tej Piastówny zrodziły się dwie córki (Anna i Jadwiga), a papież Urban VIII w 1368 r. udzielił dyspensy na ślub wbrew protestom Adelajdy, to po śmierci Kazimierza (1370) wdowa nie otrzymała uprawnień po zmarłym monarsze, jednakże ze skarbca przekazano jej 33 grzywny srebrne i kosztowności. Wyjechała na Śląsk, gdzie wyszła ponownie za mąż ${ }^{25}$. Ale kiedy Władysław Jagiełło owdowiał w 1399 r., za radą panów drugą jego żoną została Anna, wnuczka Kazimierza i Jadwigi, ze względu na pamięć społeczeństwa o królewskim rodzie Piastów.

\section{Dynastia Jagiellonów}

Po śmierci Kazimierza Wielkiego, zgodnie z wcześniejszymi ustaleniami między Wawelem a Budą, tron polski objął siostrzeniec zmarłego monarchy, a więc po kądzieli Piast, Ludwik Andegaweński (1326-1382), od 28 lat władający Węgrami, w którego imieniu wielkorządy sprawowała matka, Elżbieta (1305-1380), wdowa po Karolu Robercie. Wprawdzie unia obu państw okazała się nietrwała, ale dziedzictwo tronu zostało uchwalone w wyniku porozumienia z możnowładztwem, za cenę istotnych dla rycerstwa przywilejów, dla jednej z trzech córek nowego władcy, Jadwigi. Polscy panowie nie dopuścili jednak - kierując się racją stanu - do jej zamierzonego w dzieciństwie małżeństwa z austriackim Habsburgiem Wilhelmem i doprowadzili na mocy porozumienia w Krewie (1385) do jej małżeństwa z wielkim księciem litewskim Jagiełłą, który po przyjęciu chrztu w lutym roku następnego zasiadł na tronie pol-

\footnotetext{
${ }^{24}$ J. Długosz, Roczniki czyli Kroniki sławnego Królestwa Polskiego, Księga X, tłum. J. Mrukówna, Warszawa 1976, s. 225 n. Zob. K. Pieradzka, Jadwiga, królowa Polski, żona Władysława Łokietka, PSB X (1962), s. 290 n.

${ }^{25}$ Red., Jadwiga, królowa Polski, trzecia żona Kazimierza Wielkiego, PSB X, s. 291 Starsza córka, Anna, została wydana za mąż na Węgrzech za Wilhelma hr. Cylli.
} 
skim i zajmował go do śmierci w 1434 r. jako najdłużej panujący w Koronie monarcha. Od jego pierwotnego imienia nowa dynastia zyskała miano Jagiellonów. Rządy ich - aż do wymarcia - trwały niemal dwa stulecia, do 1572 r. i objęły cztery pokolenia, zakończyły się zaś zawarciem trzy lata wcześniej trwałej unii między Królestwem Polskim i Wielkim Księstwem Litewskim, które w ramach Rzeczypospolitej Obojga Narodów zostały zwieńczone obraniem „królem” przedstawicielki ostatniej generacji, Anny Jagiellonki, córki Zygmunta I Starego, a siostry Zygmunta II Augusta. Warunkiem objęcia tronu przez kolejnego - wybranego podczas wolnej elekcji - władcę miało być jej poślubienie ${ }^{26}$.

Założyciel dynastii zastał sytuację dotąd niespotykaną - został bowiem mężem koronowanej monarchini, a formalnie „króla” i do śmierci Jadwigi w 1399 r. jego małżonka zajmowała szczególną pozycję, a na tronie panował swoisty dualizm, przy czym Władysław był od 1386 r. pełnoprawnym władca, a układ stosunków między parą na Wawelu świadczył o doskonałym realizowaniu zasad kultury politycznej. Po przedwczesnej śmierci Andegawenki wdowiec - jak donosi Długosz - chciał powrócić na Litwę (w co nie bardzo należy wierzyć) ale dostojnicy mu to wyperswadowali, wszak zbyt silne interesy łączyły Koronę i Wielkie Księstwo. Co więcej, z myślą o kontynuacji dynastycznej po kilku latach (1402) zawarł małżeństwo z Anną, córką Wilhelma hr. Cylli, wspomnianą wnuczką Kazimierza Wielkiego. Z tego związku narodziła się córka Jadwiga (1408-1431), którą do chwili narodzin synów królewskich zamierzano wydać za Fryderyka z linii margrabiów brandenburskich i osadzić w przyszłości na Wawelu.

Władysław Jagiełło nie był zachwycony urodą drugiej małżonki, toteż kiedy powtórnie owdowiał, nie pytając dostojników o zdanie, w 1417 r. ożenił się ku powszechnemu oburzeniu z poddanką, w dodatku niemłodą i wdową po trzech mężach, Elżbietą Granowską, a kiedy ta zmarła trzy lata później, pojął w 1422 r. za radą w. ks. Witolda młodziutką Sonkę (zm. 1461) z ruskiego rodu kniaziów Holszańskich. Koronowana - tak jak poprzedniczki - na Wawelu, wydała na świat trzech synów - Władysława (1424-1444), Kazimierza (zmarł w niemowlęctwie) i Kazimierza Andrzeja (1427-1492), który przeszedł do historii z przydomkiem Jagiellończyk i od 1440 r. zasiadał na tronie litewskim, a od 1447 r. również na polskim.

Władysław Warneńczyk zginął jako dwudziestolatek w stanie bezżennym, natomiast jego młodszy brat poślubił w 1454 r. Elżbietę z rodu wiedeńskich Habsburgów, która go przeżyła i zmarła w 1505 r. na Wawelu jako powszechnie szanowana królowa - wdowa, zwłaszcza że pod bokiem nie miała synowej - rywalki, jako że Jan Olbracht był kawalerem, a Aleksander Jagiellończyk objął w 1501 r. rządy na Wawelu bez wyznającej prawosławie wielkiej księżnej Heleny, która do końca życia (zm. 1513) pozostawała na Litwie. Z wielodzietnego małżeństwa Kazimierza i Elżbiety pochodziło kilkanaścioro dzieci, w tym sześciu synów (Władysław, Kazimierz, Jan Olbracht, Zygmunt i Fryderyk), których ojciec widział na czterech stolicach - Wawel, Wilno, Hradczany i Buda) i zamiar ten został zrealizowany, tyle że z pewnymi modyfikacjami. Los jednak zdarzył, że tak rozrodzona dynastia miała zaniknąć już w następnym pokoleniu.

Pozbawiony początkowo perspektyw na koronę Zygmunt, który miał przez ponad czterdzieści lat zasiadać na tronach polskim i litewskim (1506-1548), jako książę głogowski

\footnotetext{
${ }^{26}$ Odsyłam tu do mojej syntezy: Polska w drugim tysiqcleciu, t. 1: Czasy narodu i państwa szlacheckiego, Toruń 2007, s. 93-176 (część II, poświęcona państwu Jagiellonów 1386-1572). Zob. też dane o dynastii: Z. Wdowiszewski, Genealogia Jagiellonów i Domu Wazów w Polsce, Kraków 2005; J. Tęgowski, Pierwsze pokolenia Giedyminowiczów, Poznań-Wrocław 1999. Syntetyczny zarys dziejów rodu: Dynastie Europy, s. 155-177 (tam również tablice genealogiczne).
} 
i opawski na Śląsku przezornie nie zawarł małżeństwa, gdyż nie mógłby mierzyć zbyt wysoko, ale przez lata żył w związku nieformalnym z urodziwą mieszczką z Telnitz, Katarzyną, która jako król wydał za mąż za jednego ze swoich współpracowników, zadbał też o wyposażenie trójki nieślubnych dzieci, syna Jana „z Książąt Litewskich” (tak był nazywany) uczynił nawet biskupem wileńskim. Na Wawelu u boku monarchy zasiadały kolejno dwie monarchinie - od 1512 r. Barbara (zm. 1515) córka wojewody siedmiogrodzkiego Stefana Zapolyi, a od 1518 r. Włoszka Bona Sforza, córka księcia Mediolanu. Wygrała ona w konkurencji z innymi kandydatkami.

Wszystkie małżeństwa Jagiellonów miały charakter polityczny, oczywiście z wyjątkiem dwóch zawartym samodzielnie z poddankami - o jednym (Granowska) była mowa, a drugie dotyczyło ostatniego z rodu. Zygmunt August został ożeniony przez rodziców z austriacką Elżbietą, ale było to małżeństwo nieudane (epileptyczka, wcześnie zmarła), natomiast całe państwo wzburzyła wiadomość o poślubieniu przezeń jako wdowca Litwinki Barbary z Radziwiłłów, która wstrząsnęła całą monarchią, a z czasem przeszła do wielkiej romantycznej legendy. Trzecie małżeństwo, z Katarzyną siostrą Elżbiety (podobnie jak ona chorą na epilepsję) zawarte w 1553 r. zakończyło się staraniami Zygmunta Augusta o rozwód. Dynastia wygasła niejako na własne, czyli inicjatorów wiedeńskich małżeństw, życzenie.

Za Jagiellonów dawały o sobie znać nowe czasy. Władcy, skrępowani narzucanymi żonami, usiłowali się interesować towarzyszkami życia, które znali „z portretu”, wcześniej im nadsyłanych miniatur, często podretuszowanych. Toteż Władysław Jagiełło popadł w irytację, kiedy porównał konterfekt Anny z oryginałem i nawet nie chciał się żenić. Zygmuntowi Staremu wysłani do Włoch zaufani dworzanie nadsyłali informacje o urodzie Bony (nawet przekazane im przez dwórki księżniczki wymiary!), a ona sama odmłodziła się o cztery lata, gdyż autentyczny wiek (22 lata) wydawał się jej matce zbyt poważny. Nawiasem mówiąc oblubieniec przekroczył wtedy pięćdziesiątkę.

Wszystkie królowe były koronowane, choć rodaczki po sporych trudnościach. Odgrywały poważną rolę w polityce, przy czym na ogół ,z tylnego siedzenia”. Bona, osoba o znakomitym umyśle, doskonały strateg, była jednak fatalnym taktykiem. Toteż po śmierci męża nie mogła znieść „emerytury” i rozbratu z synem, na swoje nieszczęście na starość wróciła do ojczyzny. Nie brakowało skandali obyczajowych (Jadwiga, Anna, Sonka, Barbara Radziwiłłówna). A renesansowi władcy radzili sobie organizując prywatne życie, przykładem może tu być zięć Zygmunta i Bony, Henryk Młodszy z Braunschweig - Wolfenbüttel i towarzysząca mu w trakcie trwania dwóch małżeństw dama dworu pierwszej żony, piękna Ewa von Trott, ulokowana w jednym z zamków, którą książę dla zachowania pozorów nawet teatralnie „uśmiercił” i nawet urządził jej pozorny pogrzeb. Była to druga połowa XVI w. Wiadomość o tym fakcie miała uspokoić oficjalną małżonkę, Zofię z Jagiellonów ${ }^{27}$.

\section{U progu czasów nowożytnych}

Skandal z Wolfenbüttel stał się głośny w Niemczech owych czasów, jednakże nie przerwał książęcego romansu. Podobnie - choć nie na taką skalę - radzili sobie monarchowie w Rzeczypospolitej szlacheckiej, zwłaszcza kiedy racja stanu stawiała ich w sytuacji grote-

\footnotetext{
${ }^{27}$ J. Pirożyński, Die Herzogin Sophie von Braunschweig-Wolfenbüttel aus dem Hause der Jagiellonen (1522-1575) und ihre Bibliothek, Wierbaden 1992, s. $37 \mathrm{nn}$.
} 
skowej. Wybór nieatrakcyjnej pięćdziesięcioletniej bigotki Anny Jagiellonki na tron po śmierci Zygmunta Augusta miał się wiązać z poślubieniem jej przez Henryka Walezego, który spokojnie mógłby być jej synem. Toteż Francuz o małżeństwie tym ani myślał, a sprawa rozwiązała się wraz z jego ucieczką do ojczyzny po śmierci panującego tam brata. Za to następny monarcha, Stefan Batory poślubił Annę, która wraz z nim została koronowana (różnica wieku w tym wypadku nie była tak rażąca, choć spora), ale po nocy poślubnej unikał małżonki jak diabeł święconej wody, za to uwił sobie gniazdko w okolicach Grodna. Za to po jego śmierci (1586) Anna wystąpiła w roli królowej - wdowy i godnie pełniła ją do śmierci (1596) u boku siostrzeńca, Zygmunta III Wazy, syna Jana III szwedzkiego i Katarzyny Jagiellonki. Ten był wierny dwom kolejnym żonom z rodu Habsburgów, Annie i Konstancji, za to poślubienie siostry po śmierci pierwszej z nich wywołało wzburzenie wśród szlachty i było nazywane kazirodztwem.

Władysław IV (1632-1648) nie bardzo zachowywał wierność Cecylii Renacie (córce cesarza Ferdynanda II), a po jej śmierci Ludwice Marii, nie krył się ze swymi miłostkami przypominającymi antenata po kądzieli, Jana Olbrachta. Żonę odziedziczył po bracie wraz z koroną Jan Kazimierz, pozostający pod jej wpływami w działalności publicznej ${ }^{28}$. Równie jak ona była popularna inna Francuzka, Maria Kazimiera, zasiadająca na tronie u boku Jana III Sobieskiego, która po śmierci męża (1695) powróciła na starość do kraju przodków. W przybranej ojczyźnie wśród potomnych cieszyła się znacznym rozgłosem, niekoniecznie w pozytywnym znaczeniu. Do jej popularności przyczyniła się świetnie napisana choć publicystyczna monografia pióra Tadeusza Żeleńskiego-Boy’a.

Niemieckie małżonki obu Sasów na polskim tronie pozostawały w ich cieniu, a ojciec - August II - nie krył się ze swymi nadzwyczaj licznymi miłostkami zarówno w Rzeczypospolitej, jak i nad Łabą. Katarzyna z Opalińskich Leszczyńska została wprawdzie wraz z mężem koronowana dnia 4 października 1705 r. (po raz pierwszy uroczystość miała miejsce w Warszawie) i do końca życia używała tytułu królewskiego, ale miało to miejsce niemal zawsze na wygnaniu, gdzie zmarła w 1747 r. ${ }^{29}$ Ostatni król Rzeczypospolitej, znany bardziej z młodzieńczego romansu z wielką księżną Katarzyna, przez ponad trzydziestoletnie panowanie pozostawał oficjalnie w stanie kawalerskim, co oczywiście nie było równoznaczne z przestrzeganiem celibatu. Zanim zasiadł na tronie, uległ wdziękom piętnastoletniej Elżbiety z Szydłowskich, która w 1769 r. została wydana za wdowca, generała Jana Jerzego Grabowskiego, prawdopodobnie z inicjatywy króla, którego de facto utrzymywała do końca przy sobie, mimo różnych chwilowych kochanek. Z mężem miała jedną córką, ze Stanisławem Augustem dwie córki i trzech synów, jeden z nich, Stanisław Grabowski był ministrem oświaty w Królestwie Polskim. Uważano ją za morganatyczną żonę, u boku króla pozostawała do 1794 r. Stanowiła obiekt dosyć powszechnej niechęci jeśli nie nienawiści, o czym świadczyły inwektywy obiegające Warszawę ${ }^{30}$.

Ten z konieczności pobieżny przegląd, stanowiący zapowiedź większej całości, kończymy konkluzją: droga do emancypacji kobiet rozpoczęła się w Polsce od rodzin monarszych

\footnotetext{
${ }^{28}$ Wyniesienie - dosyć niespodziewane, w 1669 r. - na tron księcia Michała Korybuta Wiśniowieckiego (zm. 1673) sprawiło, że jego żoną została córka cesarza Ferdynanda II, arcyksiężniczka Eleonora. Ale wkrótce przeciwnicy słabego monarchy zaczęli zamyślać o rozwodzie pary królewskiej, niezależnie od planów detronizacyjnych monarchy. Zob. PSB XX (1975), s. 605 nn.

${ }^{29}$ PSB XII (1966-1967), s. 217 nn.; XLI (2002), s. 610.

${ }^{30}$ W. Dzwonkowski, S. Wasylewski, Grabowska Elżbieta z Szydlowskich (1748/9-1810), PSB VIII (1959-1960), s. 475 nn.; J. Michalski, Stanisław August Poniatowski, PSB XLI (2002), s. 639.
} 
już w średniowieczu, a efekty były widoczne od przełomu między dynastiami piastowską i jagiellońska, zwłaszcza w czasach Odrodzenia i Baroku, a były szczególnie widoczne w ostatnim stuleciu istnienia Rzeczypospolitej przedrozbiorowej. Objęły od XVI wieku również kręgi możnowładcze i zamożną szlachtę. Do niższych warstw ludności miały dojść dopiero wówczas, kiedy naród stanowy przekształcił się w nowoczesny, klasowy, czyli pod zaborami i po odzyskaniu niepodległości ${ }^{31}$.

\section{Summary}

On the Throne and beside the Throne. On Women in the Public Life of Poland Prior to the Partitions

The royal throne was a permanent element of feudal political culture, and the institution of the monarchy, albeit decidedly less significant, has survived until today, playing a primarily symbolic role in the democratic systems in Europe.

The subject of the paper looks at the role of Polish rulers' wives, as the majority of monarchs started a family, and their offspring later took the throne. This was the case of both great dynasties - the Piasts, from the mid- $10^{\text {th }}$ century, i.e. from the baptism of Mieszko I, and the Jagiellons (until 1572). After these dynasties ended, the period of elective kings, who were crowned with their wives, started.

Over the years, at the very least, the informal role of the queens was growing. This process paved the way to women's liberation, and, as of the end of the $18^{\text {th }}$ century, it also encompassed the families of magnates and affluent gentry. A meaningful statement can be found in the poetry written by Bishop Ignacy Krasicki in the latter half of the same century, when he addressed men saying: "we rule the world, and women rule us".

The paper is only a sketch and promises a more in-depth monographic study.

\footnotetext{
${ }^{31}$ Szerzej M. Kosman, Polska w drugim tysiącleciu, t. II, Toruń 2007.
} 
